\title{
'Very urgent, very difficult and quite possible': changing students' attitudes to notemaking by encouraging user generated content
}

Tom Burns

London Metropolitan University, UK

\section{Sandra Sinfield}

London Metropolitan University, UK

\section{Debbie Holley}

London Metropolitan University, UK

\section{Kate Hoskins}

London Metropolitan University, UK

\section{Abstract}

As soon as one can no longer think things as one formerly thought them, transformation becomes both very urgent, very difficult and quite possible (Foucault, 1980:154).

This paper explores the role that notemaking strategies can play as part of an emancipatory pedagogy designed to empower students. We will argue that being taught active notemaking is fundamental in enabling students to use information with confidence and thus that notemaking allows students to gain a voice (Bowl, 2005; Burns et al., 2006) within their own education. Rather than taking a psychological approach to notemaking, we suggest that notemaking allows students to take ownership of ideas and concepts in powerful ways (Gibbs, 1994 cited Burns and Sinfield, 2004), ways that reinforce understanding and build knowledge. These processes and practices can essentially help students to learn what they want to learn - and, pragmatically, to write essays that are adequately researched and correctly referenced (Burns and Sinfield, 2004). The final focus will be on the collaborative 
development of NoteMaker, a Reusable Learning Object (RLO) designed for use across the university - and across the sector.

\title{
Setting the context
}

Debates over strategies such as the practice of notemaking tend to centre on memory: does notemaking improve the recall of significant information? (Buzan, 1989; Buzan and Buzan, 1999) and/or result in behaviour change: does information in notes appear in assignments and examinations (Sutherland, Badger and White, 2002)? And our students do tend to want to learn and re-call information for their essays and exams. However, the key point for us is that students must make notes in some form because this positions them more powerfully within academic discourse, offering them opportunity to become stakeholders in their own educational experiences. Making notes enables students to record knowledge claims (Holmes, 2002 cited Burns and Sinfield, 2003), test ideas and record bibliographic details. Proactive notes, when combined with an active revision cycle (Burns and Sinfield, 2004), can be part of the student's learning processes, fostering ownership and voice (Bowl, 2005; Burns et al., 2006).

A critique of this position can be seen in the discourses around deep and surface learning, whereby notemaking and other 'study skills', can be marginalised by the 'academy'. Haggis, (2003: 97) comments that:

\begin{abstract}
At the time of entry, students are expected to arrive already prepared to engage with ideas, texts and debates. The plethora of universities offering 'Study Skills', 'Transferable Skills' and 'Higher Education Orientation' courses indicates the fallacy of this assumption.
\end{abstract}

The original research on deep and surface learning was undertaken with students and their reading strategies, and suggested that students varied their strategy according to the task (Marton and Saljo, 1976; Marton et al., 1997). A model of students and how they choose to engage with study in a particular instance developed, which has been polarised in some texts 
to imply deep learning as 'good' and surface learning as having more negative connotations (Richardson, 2000).

Haggis (2003: 98) offers a different view of the learner, where the learner may be a person who is experiencing difficulty with unexplained norms and values in higher education, and He or she may be exhausted from part-time work or parenting, distracted by family or financial problems, or lacking the fundamental confidence, self-esteem or health to engage in the ways that are assumed to be both desirable and possible.

The experiences of these different kinds of learners, pushed through a mass education system by a raft of government initiatives, do not meet with the expectations of academics driven by a research agenda: new and different ways of teaching and learning are needed. If 'the system is to grow into a genuinely accessible form of education for $50 \%$ of 18 year olds, in addition to the widest possible range of adults learning throughout their lives, it is going to have to find new ways of conceptualising its core values and activities' (Haggis, 2003: 102).

We argue that appropriate notemaking is not only central to success at university but the practices it fosters are also central characteristics of the reflexive self (Giddens, 1996). That is, good notemaking strategies involve not just passively summarising information, but actively absorbing, analysing, reflecting upon and using information. This form of notemaking, we argue, can be seen as a cyclical process that fosters analytical and creative attributes that are critical for a citizen in a globalised information driven society. Indeed, as Foucault (1980: 39) argues, notemaking is:

The point where power reaches into the very grain of individuals, touches their bodies and inserts itself into their actions and attitudes, their discourses, learning processes and everyday lives.

\section{Notemaking: an empowering practice for students?}

Thomas (2001), as with Freire (1997), argues that a traditional education can position students as 'accepting and passive' (Thomas, 2001: 32). However, Freire (1997:32) argued 
for education as an opportunity for 'empowerment' with 'the primary function of education and educative processes to be the dynamic development of critical consciousness, which involves critical thought and action'. Learning is posited as a reflexive and critical endeavour, enabling the learner to challenge disempowering political practices; it is here that we position active notemaking - and it is for that reason that we collaborated to design and build an interactive and empowering notemaking resource.

\section{Making Notes}

Medway, et al (2003: 41), and our own observations and anecdotal evidence from across the sector, indicates that less and less notemaking is being undertaken by students and thus typically 'students may avoid learning to take notes and acquiring skills of summarising, synthesising and ordering that require the material to be actively processed and understood'. Medway (2003: 41) further argues that by not developing these essential study skills, students are disempowered to engage on a deep level with their 'learning processes'.

The following section will briefly discuss some key notemaking forms and their strengths and weaknesses - and will move on to discuss the NoteMaker, a Reusable Learning Object (RLO) designed to introduce students to empowering notemaking practice that was developed here at London Met under the aegis of two of the university's Centres for Excellence in Teaching and Learning (CETLS): RLO - and LearnHigher CETL.

\section{Linear notes}

Linear (line by line) notes are the most typical notemaking form adopted by students, and university staff, when they do make notes. Typically this form involves making lists, perhaps with bullets or numbers - with highlighting and underlining used to identify key or important topics. Whilst this practice has an instant logic and can be very neat and appealing to look at, there is a danger that it locks the notemaker into the argument and evidence structure used by the subject; thus it is too passive and is the form most likely to promote conscious or unconscious plagiarism (Burns and Sinfield, 2004). Indeed, this is the form most akin to notetaking and is not notemaking at all. That is, it tacitly encourages taking down the words, 
thoughts and argument structures of others rather than breaking information down into its component parts and re-structuring it for oneself. We posit that it is the active, intellectual and critical engagement with ideas fostered by good notemaking practices that put the learner at the centre of their own learning, and that makes notemaking an aspect of emancipatory practice. For it is only when students wrestle with ideas and information for themselves that they gain the means to contest, or accept (!), dominant political discourses and gain their own voice (Bowls, 2005; Burns et al., 2006).

\section{Cornell notes}

Cornell notes are similar to linear notes in that they too have a linear form. However, the Cornell system is intrinsically more active than the straightforward linear format, requiring the notemaker to engage reflexively, analytically and critically with the notes that they make. Typically in the Cornell system, the notemaker divides their page in two: one side is for the collection of notes; the other is for their critical commentary upon the notes. It is here that the notemaker can indicate immediately why the notes have been made and how they might use the information therein (Burns and Sinfield, 2004). The key benefit of this strategy is that it encourages students to reflect on why particular information is important and why they have noted it. It encourages critical reflection and the making of sense, meaning and connections. It puts the student's understanding and participation at the centre of the knowledge construction process (Burns and Sinfield, 2004) and it is here that we are arguably moving from notetaking to notemaking.

\section{Mindmaps}

Mindmaps are perhaps the most familiar non-linear notemaking format. Also known as spidergrams or nuclear notes, these non-linear notes are encouraged by Buzan and Buzan (1999) as an active and creative way to both generate and capture ideas. The idea with the mindmap is to put the main topic in the centre of a diagram that the notemaker builds by drawing out subsidiary lines with ideas linked to the main topic. The mindmap can be made memorable by the notemaker with the use of colour and the construction of cartoons or pictures with a mnemonic function. Buzan's argument is that it is literally more engaging 
because it harnesses both halves of the brain, the logical left and the creative right. When working with students we have encountered resistance to the use of non-linear notemaking formats; but once adopted, students feed back that these are the formats that prove to be the most powerful in promoting their concentration, participation, learning and active engagement.

\section{Concept Maps}

The concept map, as with the mindmap, offers a graphical representation of key concepts organised hierarchically - and with relationships between concepts or sub-concepts indicated by links and connections. A concept is defined as 'a perceived regularity in events or objects, or records of events or objects, designated by a label' (Novak and Canas, 2006: 1). The psychological foundations with respect to the use of concept maps are that the material to be learned must be conceptually clear and stated in language relevant to the learner's prior knowledge; the learner must possess prior knowledge; and the learner must choose to learn meaningfully (Novak and Canas, 2006: 2-3) - and it is with pedagogical strategies that place the learner as active within their own learning that the tutor attempts to motivate students to learn in socio-political/emancipatory ways, that is, to learn meaningfully.

\section{Pattern notes}

Pattern notes are the name that can be given to any non-linear format and this is the one that we teach the most frequently. The pattern note format is more flexible than Buzan and Buzan's strict one word per line mindmap and when teaching it we stress that it is both a notemaking and a learning tool. As with the mindmap, the idea is that students select and connect information for themselves, enabling them to synthesise a range of complex ideas. Students have to dissect, engage with and re-structure complex concepts on their own terms and they have to engage with a range of diverse and often unfamiliar ideas (Gibbs 1994, cited Burns and Sinfield, 2004) as they do so. The argument is that this very selection/connection process is itself an active learning strategy; thus this can be seen as an extremely powerful, active notemaking system. Pattern notemaking allows the formation of 'a set of unique pattern notes' (Burns and Sinfield 2004: 93) each time the student works. Typically when teaching this we stress that students build in their own mnemonic triggers at the notemaking stage and thus each set of notes they make is unique and consequently more memorable. 
Pattern notemaking is difficult, time-consuming and often frustrating. It requires thought, concentration and active decision-making. It can be worrisome and aggravating - but it can also be creative, challenging and as powerful as it is non-hierarchical. We argue that when taught, supported and rehearsed, this system allows for ownership of ideas and can be central to transformatory and emancipatory education, for according to Foucault (1980: 154):

As soon as one can no longer think things as one formerly thought them, transformation becomes both very urgent, very difficult and quite possible.

And that is the goal with active notemaking - it is the student's first struggle with information and after this struggle it should be more difficult to think of things as the previous speaker or author thought them and more difficult to think of them as you once thought them. We argue that in this way, notemaking places the student at the centre of their learning, and thus can provide the potential for a transformative experience.

\section{Development of the web based notemaking tool (RLO)}

Thus whilst notemaking may be overlooked, we argue that it is central to emancipatory education as a socio-political tool that empowers students to navigate, negotiate, excavate, learn and own information that they are reaching for themselves (Rogers, 1994). For these reasons LearnHigher and RLO-CETL came together, to collaborate for a 'transformative pedagogy' (Hooks 1994, cited in Bowl, 2005) and produce a notemaking tool that would enable students their own access to these ideas and strategies, and that would create a resource that subject academics could teach from or to which they could guide their students. The notemaking RLO is composed of three parts:

- An introduction to why we make notes (see Figure 1)

- A consideration of what sort of notes to make (featuring linear, Cornell and pattern notes - illustrated in Figure 2) - and

- A final section that initially hosted only a brief 'How to make notes' lecture within a notemaking tool that allows the student to view/pause the video and make notes (see 
Figure 3). We have now added several different mini-lectures and demonstrations for students to practice upon.

\section{User-generated content}

Following evaluation, one extension of the tool requested by students was the ability for the students themselves to enter their own content, and indeed if the tool is to be used and reused it will be because of its usefulness to students themselves. In this instance students were simply given access to the section where the video of the lecture was originally placed and given the option to upload any media file (podcasts, images, videos, mp3s) they wanted to make notes upon. This increased the functionality of the tool - but more than that, it increases student control of the use to which the tool can be put.

A further iteration of the prototype in discussion, is to offer the notemaker the option of placing their notes into a 3D space. The motivation of adding this further functionality is to promote a sense of immersion and being physically a part of one's learning. Such techniques were adopted by ancient orators in order to remember speeches using a combination of organisation, visual memory and association (Yates, 1992). In such a prototype users will be offered the choice of mapping their notes onto an already existing 3D space or (for greater cognitive payback) offered the opportunity to create simple 3D spaces prior to mapping the notes onto them.

We have invited members of the LDHEN to use the NoteMaker and to report back their comments and criticisms to enable future developments, and that offer is extended to readers of this paper. Currently response has been positive with respect to use of the tool and the experimentation and exploration of notemaking that it has supported. There has been some disappointment that there are no 'Save' and 'Edit' functions - but we have included links in our Extra Resources section (http://learning.londonmet.ac.uk/TLTC/learnhigher/notemaker/page3.html) to Open Source software such that users can find and download their own notemaking resources for consistent use once the exploration stage has been engaged with. 
Figure 1. Why make notes?

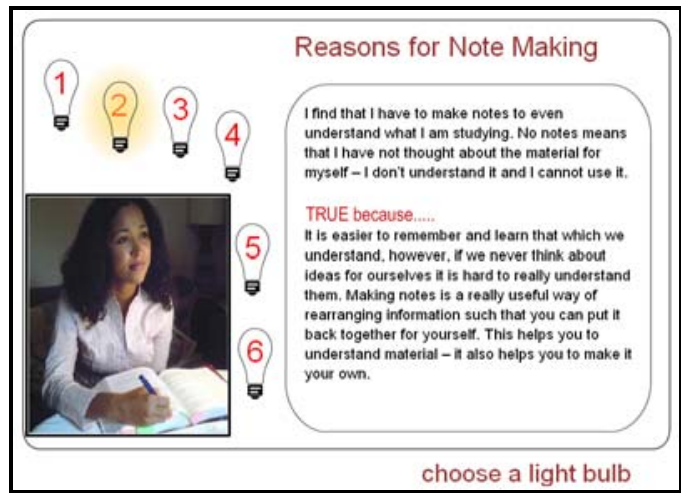

Figure 2. Pattern note example.

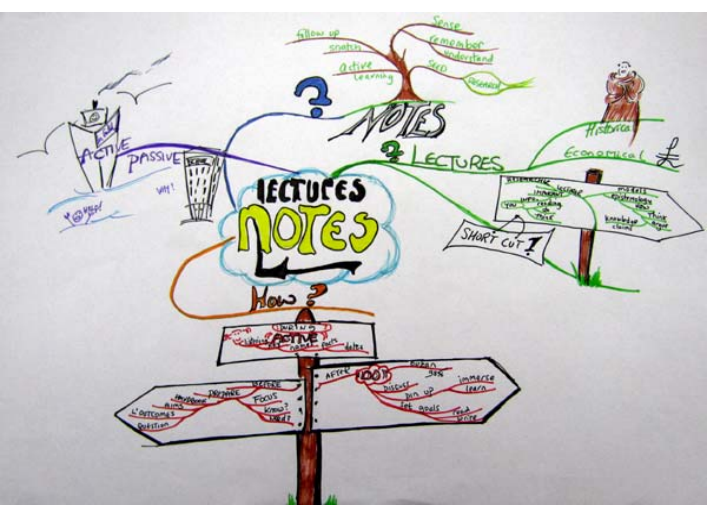

Figure 3. Web based tool prototype (and link to staff tutorial).

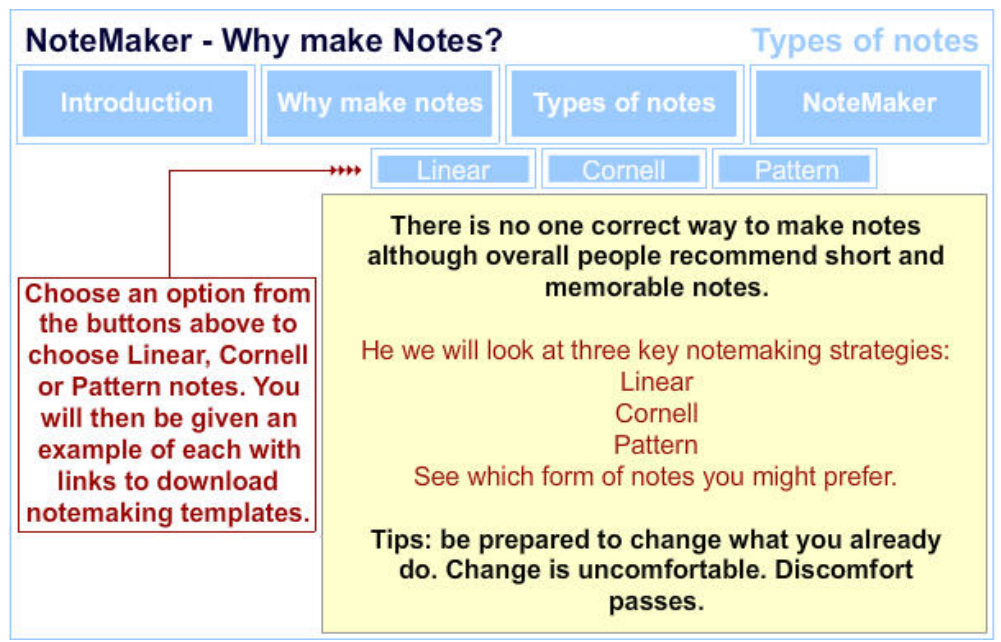

The NoteMaker:

http://www.learnhigher.ac.uk/learningareas/notemaking/home.htm

Staff tutorial drafted to help with embedding:

http://www.catsconsulting.com/workshops/notemaking/player.html

\section{Conclusion}

We have argued that notemaking allows students to take ownership of theories and concepts and to critically engage with ideas (Gibbs, 1994 cited Burns and Sinfield, 2004) which reinforces understanding and builds knowledge (Burr, 2003). These processes and practices 
can, socio-politically, help students to learn what they want to learn and, pragmatically, to write essays which are adequately researched and correctly referenced and to revise for and pass exams (Burns and Sinfield, 2004). Our work with the first year students in a Business School shows a pattern of narrations of reported practice of success but when students are successful in the detail of their study, this is often dismissed as 'surface learning' (Entwistle, 2000). Our thesis is that active notes become successful academic scripts indicative of 'deep learning' and thus form aspects of transcendent and transformative education experiences (Satterthwaite et al., 2004).

We argue that active, creative notemaking strategies empower and engage students and place the learner truly at the centre of their own learning. Drawing these elements together, we discussed collaborative action to develop transformative pedagogy in action: the collective generation of a notemaking RLO that was designed as a pedagogical tool for staff and student use. Our argument is that the teaching of study and academic skills is more than fixing deficit students, it is more than academic socialisation and more than the process of inducting students into academic literacies - rather it is emancipatory and socio-political and when undertaken well it fosters student learning, power and voice (Bowl, 2005; Burns et al., 2006).

\section{Resources developed by: Richard Haynes and James Connor Presented at LDHEN Symposium April 2009}

\section{References}

Bowl, M. (2005) 'Valuing diversity in the social science curriculum', Learning and Teaching in the Social Sciences 2(2) pp 121-136.

Burns, T. and Sinfield, S. (2003) Essential study skills: the complete guide to success @ university. London: Sage.

Burns, T. and Sinfield, S. (2004) Teaching, learning and study skills: a guide for tutors. London: Sage. 
Burns, T., Sinfield, S. and Holley, D. (2006) 'The silent stakeholder: an exploration of the student as stakeholder in the UK Government e-learning strategy 2005', The Corporate Social Responsibility Conference. Edrine, Turkey, May.

Burr, V. (2003) Social constructionism. East Sussex: Routledge.

Buzan, T. (1989) Use your head. London: BBC Publications.

Buzan, B. and Buzan, T. (1999) The mind map book. London: BBC Publications.

Entwhistle, N. (2000) 'Approaches to studying and levels of understanding: the influences of teaching and assessment', Higher Education: Handbook of Theory and Research 15 pp 156-219.

Foucault, M. (1980) Power/knowledge: selected interviews and other writings 1972-1977, edited by Colin Gordon. London: Harvester. (See in particular 'The confession of the flesh' [interview, 1977]).

Freire, P. (1977) The pedagogy of the oppressed. Harmondsworth: Penguin.

Giddens, A. (1996) Consequences of modernity. Cambridge: Polity Press.

Haggis, T. (2003) 'Constructing images of ourselves? A critical investigation into 'approaches to learning' research in higher education', British Educational Research Journal 29(1) pp 89-104.

Marton, F., Hounsell, D. and Entwistle, N. (1997) The experience of learning: implications for teaching and studying in higher education. Edinburgh: Scottish Academic Press.

Marton, F. and Saljo, R. (1976) 'On qualitative differences in learning: 1 outcome and process', British Journal of Educational Psychology 46(1) pp 4-11. 
Medway, P., Rhodes, V., Macrae, S., Maguire, M. and Gewirtz, S. (2003) Widening participation through supporting undergraduates: what is being done and what can be done to support student progression at King's? London: King's College Department of Education and Professional Studies.

Novak, J.D. and Canas, J.C. (2006) The theory underlying concept maps and how to construct them. ONLINE: www.ihmc.us (Accessed: 19 December 2006).

Richardson, J. (2000). Researching student learning. Buckingham: Open University Press.

Rogers, C. (1994) Freedom to learn. Upper Saddle River NJ: Merrill.

Satterthwaite, J., Atkinson, E. and Martin, W. (eds.) (2004) The disciplining of education: new languages of power and resistance. Stoke on Trent: Trentham Books.

Sutherland, P., Badger, R. and White, G. (2002) 'How new students take notes in lectures', Journal of Further and Higher Education 26(4) pp 377-388.

Thomas, E. (2001) Widening participation in post-compulsory education. London: Continuum. Yates, F. (1992) The art of memory. London: Pimlico.

\section{Author Details}

Tom Burns is a Senior Lecturer in the Learning Development Unit at London Metropolitan University and co-author of Essential study skills: the complete guide to success at university and Teaching, learning and study skills: a guide for tutors. He has produced a short video, 'Take Control', which won the 1998 IVCA gold award for education.

Sandra Sinfield is Coordinator for Learning Development at London Metropolitan, co-author with Tom Burns and Learning Area Coordinator for reading and notemaking on the LearnHigher CETL. A student from a non-traditional background herself, Sandra is 
fascinated by the policies and practices of HE and the emancipatory potential of Learning Development.

Debbie Holley is Principal Lecturer in Learning and Teaching at London Metropolitan University Business School. Since joining the University from industry, she has become very interested in the use of technology to facilitate learning. Using a variety of multimedia objects within the WebCT/Blackboard environment she has successfully engaged students with blended learning. Part of the Reusable Learning Object Centre of Excellence for Teaching and Learning (www.rlo-cetl.ac.uk) team, she is working with students to develop interactive learning materials. She was recently awarded a 3 year University Teaching Fellowship.

Kate Hoskins is currently a lecturer in Youth Participation on the MSc degree at Birkbeck. She also lectures and supervises students on the MA in Education Studies at London Metropolitan University. Kate completed a Master's degree in Education and Social Policy at King's College London and is now undertaking a PhD in the policy studies centre at King's College London. 